\title{
Detection of Polymorphism of Pituitary Specific Transcription Factor 1 Gene and Its Association with Bodyweight of Fulani and Yoruba Ecotype Chickens
}

\author{
Semiu F. Bello1,2*, Mabel 0. Akinyemi' ${ }^{1}$ Rasheed B. Fatai', Muslim K. Ewuola1, Ridwan 0. Ahmed ${ }^{1}$, \\ Favour Oluwapelumi Oyelami ${ }^{3}$, Fisayo T. Akinyemi' ${ }^{2}$, Babatunde Shittu Olasege ${ }^{4}$ \\ ${ }^{1}$ Department of Animal Science, University of Ibadan, Ibadan, Nigeria \\ ${ }^{2}$ Department of Animal Genetics, Breeding and Reproduction, College of Animal Science, South China Agricultural University, \\ Guangzhou, People's Republic of China \\ ${ }^{3}$ Department of Animal Science, Shanghai Jiao Tong University, Shanghai, People's Republic of China \\ ${ }^{4}$ School of Chemistry and Molecular Bioscience, University of Queensland, Brisbane, Queensland, Australia \\ Email: `bellosemiu@stu.scau.edu.cn, larakinyemi@gmail.com, fatairasheed36@gmail.com, ewuolam@yahoo.com, \\ ahmedridwan341@gmail.com, oyefavour@gmail.com, fisayo@sjtu.edu.cn, babatundeolasege@gmail.com
}

How to cite this paper: Bello, S.F., Akinyemi, M.O., Fatai, R.B., Ewuola, M.K., Ahmed, R.O., Oyelami, F.O., Akinyemi, F.T. and Olasege, B.S. (2020) Detection of Polymorphism of Pituitary Specific Transcription Factor 1 Gene and Its Association with Bodyweight of Fulani and Yoruba Ecotype Chickens. Open Journal of Animal Sciences, 10, 278-286.

https://doi.org/10.4236/ojas.2020.102016

Received: December 28, 2019

Accepted: March 14, 2020

Published: March 17, 2020

Copyright () 2020 by author(s) and Scientific Research Publishing Inc. This work is licensed under the Creative Commons Attribution International License (CC BY 4.0).

http://creativecommons.org/licenses/by/4.0/ (c) (i) Open Access

\begin{abstract}
Pituitary Specific transcription factor 1 (PIT-1) gene is one of the POU gene family and play key roles in the regulation of muscle development which is important for body weight in chickens. This study was carried out to detect the polymorphism of PIT-1 gene and study its association with body weight in Fulani and Yoruba ecotype of Nigerian indigenous chickens. A total of 100 day-old chicks comprising of fifty chicks of Fulani and Yoruba ecotypes were used for this study. These chicks were genotyped using PCR-RFLP technique and their growth rate was also measured throughout the study. Our results showed two alleles $\mathrm{A}$ and $\mathrm{B}$ controlling genotypes $\mathrm{AA}$ and $\mathrm{AB}$ which were significantly associated with bodyweight of the chickens. Interestingly, we found out that AA genotype had the highest frequency of 0.64 and 0.76 compared with $A B$ genotype which had a frequency of 0.36 and 0.24 in the Fulani and Yoruba ecotype respectively. Furthermore, the PIT-1 genotypes (AA and AB) were significantly associated $(\mathrm{p}<0.05)$ with body weight at week 4 and week 12 in Fulani and Yoruba ecotype chicken respectively. PIT-1 gene was polymorphic in Fulani and Yoruba ecotypes of Nigeria Indigenous Chickens.
\end{abstract}

\section{Keywords}

PIT-1 Gene, Polymorphism, Chicken 


\section{Introduction}

Indigenous chickens in developing countries like Nigeria serve as one of the major sources of animal protein for the growing population. They also serve as a source of income or cash reserve especially during festive periods in the country. They are used for some religious ceremonies and recreation [1].

Nigeria Indigenous chicken can be grouped into two major categories on the basis of body size and body weight as heavy (Fulani ecotype) and light (Yoruba ecotype) [2]. These birds are reared extensively, which make them to be scavengers as they are self-reliant and hardy, capable of withstanding the abuses of harsh climate, minimal management, and inadequate nutrition [1]. They have better flavor of meat and egg, profound genetic variation in their performance and ability to breed naturally [3]. Also, they are good sitters, excellent foragers and hardy and have natural immunity against common diseases. However, they grow slowly and poor layers of small sized eggs [4].

Reference [5] found that the Fulani ecotype chicken was bigger in size than the Yoruba ecotype chicken $1.76 \pm 0.4$ and $0.79 \pm 0.21 \mathrm{~kg}$ for Fulani and Yoruba ecotypes respectively. Indigenous male chicken was also bigger in size than their female counterparts with body weight of $1.5 \pm 0.06 \mathrm{~kg}$ versus $1.29 \pm 0.04 \mathrm{~kg}$, respectively [6].

Growth is regulated by several genes and pituitary specific transcription factor 1 (PIT-1) is the most important. It plays a role in transcription factor for growth hormone, prolactin and transforming growth factor- $\beta$ genes that play the most pivotal role in controlling growth in chickens [7].

It is also involved in the development of the anterior pituitary gland and silencing adrenarche [8], and inducing differentiation of hepatic progenitor cells into prolactin-producing cells [9]. This gene is auto-regulated during expression, and the presence of this protein was reported in lactotrophs, somatotrophs, and thyrotrophs [9].

In chicken, PIT-1 gene cDNA was firstly isolated and sequenced by [10] and it is located on chromosome 1 (GGA 1) over $14 \mathrm{~kb}$ in length. The sequence of duck PIT-1 gene was submitted by Kansaku in 2006 (Genbank No.: AB258457) and the identity of PIT- 1 mRNA between chicken and duck was $86.35 \%$. In addition, the PIT-1 gene was considered as an important candidate gene since it was genetically located on GGA1 which was near the QTL region controlling growth and development in chickens [11].

The crucial regulatory function of this gene as a key candidate gene for production performance in cattle growth and carcass but not carcass and fatty traits in chicken cannot be over emphasized [12]. Also, it has been reported to influence the growth rate, carcass parameters and feed efficiency in poultry birds [13].

However, information on the selective advantage which the polymorphic types of PIT-1 confer on the body weight of Nigerian Indigenous Chickens is presently scanty. Therefore, we investigated the tendency of using the PIT-1 gene polymorphic types as a major gene for growth in Fulani and Yoruba ecotype chickens. 


\section{Methods}

\subsection{Location of the Experimental Pen}

This experiment was conducted at the Poultry Unit of the Teaching and Research Farm of Department of Animal Science, University of Ibadan, Ibadan which is situated 6 kilometers to the North of the city of Ibadan $\left(7^{\circ} 26^{\prime} \mathrm{N}\right.$ and $\left.3^{\circ} 54^{\prime} \mathrm{E}\right)$ at a mean altitude of 277 meters above sea level (Figure 1). This study was carried out between November, 2017-April, 2018.

\subsection{Foundation Stock and Experimental Birds}

Ninety mature Fulani and Yoruba ecotypes chickens (36 hens and 9 cocks for each ecotype) were purposefully sourced from selected localities within Oyo state, Nigeria and managed intensively. Natural mating of 1 cock to 6 hens was adopted and eggs were collected on daily basis and were taken to hatchery.

A total of one hundred day-old chicks comprising of fifty chicks of Fulani and Yoruba ecotype each was sampled from the chicks hatched. Chicks were tagged subcutaneously at day old and weighed at the beginning of the study using a sensitive weighing scale. They were fed with commercial chick's starter diet (24\% crude protein and $3000 \mathrm{kcal} / \mathrm{kg} \mathrm{ME}$ ) for four weeks and commercial grower's diet $(18 \%$ crude protein and $2750 \mathrm{kcal} / \mathrm{kg} \mathrm{ME})$ after four weeks till the end of the experiment. Water was provided ad libitum with medications when necessary.

Weighing of individual birds was done on weekly basis for twelve weeks.

$3 \mathrm{ml}$ of blood samples were collected through the jugular vein of the experimental birds at week 10 into an EDTA containing bottles, kept in ice box, transferred to laboratory and stored at $-20^{\circ} \mathrm{C}$ for DNA extraction.

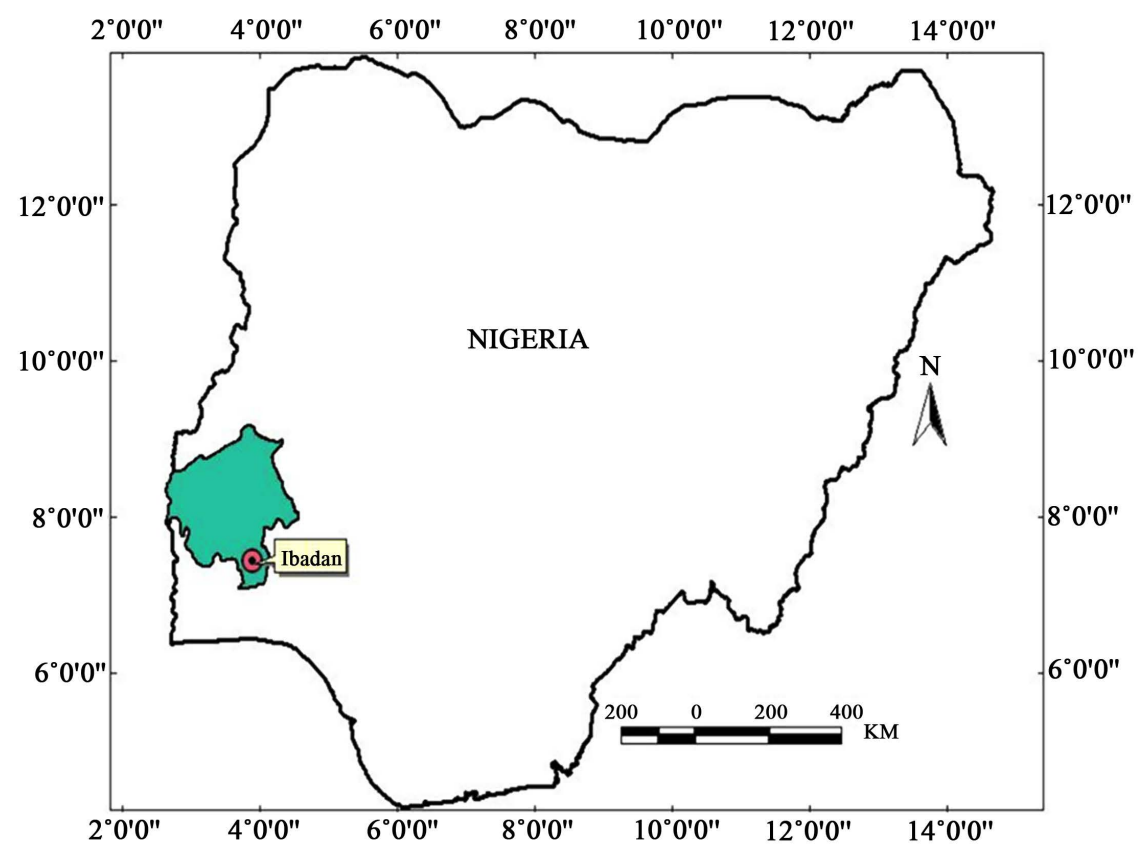

Figure 1. Map of Nigeria showing the experimental area (University of Ibadan in Oyo State). 


\subsection{DNA Extraction}

Genomic DNA was isolated using DNA extraction kit (Zymo-gDNA Miniprep kit) using the manufacturers protocol.

\subsection{Primer}

Primers reported by [14] were used to amplify 243 bp of chicken pituitary transcription factor 1 (PIT-1) gene with accession number AF029892.

Forward: 5'-GCCTGACCCCTTGCCTTTAT-3'

Reverse: 3'-CCAGCTTAATTCTCCGCAGTTT-5'

\subsection{Genotyping by PCR-RFLP Procedure}

The PCR reaction mixture consists of twenty-five (25) $\mu \mathrm{L}$ containing $2.5 \mu \mathrm{L}$ genomic DNA, $12.5 \mu \mathrm{L}$ Master mix, $9 \mu \mathrm{L}$ Nuclease Free water (NF water), $0.5 \mu \mathrm{L}$ of each forward and reverse primers. Reactions were run on a Mastercycler Gradient 5331 thermal cycler (Eppendorf) under the following thermal conditions: Initial denaturation at $94^{\circ} \mathrm{C}$ for $5 \mathrm{~min}$, followed by 35 cycles consisting of denaturation at $94^{\circ} \mathrm{C}$ for $30 \mathrm{~s}$, annealing at $55^{\circ} \mathrm{C}$ for $1 \mathrm{~min}$, extension at $72^{\circ} \mathrm{C}$ for 1 min and a final extension at $72^{\circ} \mathrm{C}$ for $2 \mathrm{~min}$.

The PCR products were digested using Hinf 1 as restriction enzyme. A total reaction volume of $15.5 \mu \mathrm{L}$ containing $5 \mu \mathrm{L}$ of PCR products, $1 \mu \mathrm{L}$ of $10 \times \mathrm{NE}$ Buffer, $9 \mu \mathrm{L}$ of Nuclease Free water and $0.5 \mu \mathrm{L}$ of restriction enzyme (Hinf I). The mixture was incubated at $37^{\circ} \mathrm{C}$ for 15 minutes. The restriction digested products were electrophoresed for 45 minutes at $100 \mathrm{~V}$ on a $1 \%$ agarose gel. Individual PCR-RFLP fragment sizes in each sample were determined using Gel Doc documentation system (Biorad USA).

\subsection{Statistical Analysis}

Genotype and allele frequencies were determined by direct gene counting method. The allele and genotype frequencies in each ecotype of chicken were tested for Hardy-Weinberg equilibrium (HWE) using POPGENE 1.32 software package.

General linear model procedure of Statistical Analysis System program [15] was used to determine the effects of the different polymorphic types of PIT-1 and sex on body weight of each ecotype. Significant means was separated using DMRT test. This model was used to estimate effect of PIT-I polymorphic types and sex on body weight:

$$
Y_{i j k l}=\mu+A_{i}+B_{j}+C_{k}+A B_{i j}+B C_{j k}+e_{i j k l}
$$

where:

$Y_{i j k l}=$ the value of the body weight on $i^{\text {th }}$ ecotype, $j^{\text {th }}$ sex and $k^{\text {th }}$ PIT-I polymorphic variant

$$
\begin{aligned}
& \mu=\text { overall population mean } \\
& A_{i}=\text { effect of the } i^{\text {th }} \text { ecotype (Fulani and Yoruba) } \\
& B_{j}=\text { effect of the } j^{\text {th }} \text { sex (cock and hen) }
\end{aligned}
$$


$C_{k}=$ effect of the $k^{\text {th }}$ PIT-1 polymorphic variant

$A B_{i j}=$ interaction effect of $i^{\text {th }}$ ecotype and $k^{\text {th }}$ PIT-1 polymorphic variant

$B C_{j k}=$ interaction effect of $j^{\text {th }}$ sex and $k^{\text {th }}$ PIT-1 polymorphic variant

$e_{i j k l}=$ random error

A Chi-squared test analysis was carried out to confirm if the observed genotype frequencies agree with Hardy-Weinberg's equilibrium expectations.

\section{Result}

The PCR-RFLP patterns of the Hinf 1 digested amplicon is presented in Figure 2.

The allelic and genotypic frequencies for Pituitary specific transcription factor 1 in Fulani and Yoruba ecotype are presented in Table 1.

The least square means (LSM \pm SD) of effect of Polymorphic types of PIT-1 gene on body weight of Fulani and Yoruba ecotype chickens is shown in Table 2.

There was no significant association $(\mathrm{p}>0.05)$ between PIT-1 genotypes and body weight of Fulani ecotype except at week $4(\mathrm{p}<0.05)$ while there was a significant association $(\mathrm{p}<0.05)$ between PIT-1 genotypes and body weight of Yoruba ecotype at week 12 only.

Table 1. Allele and genotypic frequencies of pituitary specific transcription factor 1 in Nigerian indigenous chicken.

\begin{tabular}{|c|c|c|c|c|c|c|c|}
\hline \multirow{2}{*}{ Ecotype } & \multicolumn{2}{|c|}{ Allelic frequency } & \multicolumn{3}{|c|}{ Genotypic frequency } & \multirow{2}{*}{$x^{2}$} & \multirow{2}{*}{$\mathrm{G}^{2}$} \\
\hline & A & B & $\mathrm{AA}$ & $\mathrm{AB}$ & BB & & \\
\hline Fulani & 0.83 & 0.17 & $28(0.64)$ & $15(0.36)$ & $0(00)$ & 1.77 & 2.98 \\
\hline Yoruba & 0.88 & 0.12 & $35(0.76)$ & $11(0.24)$ & $0(00)$ & 0.76 & 1.36 \\
\hline
\end{tabular}

$\chi^{2}$ : Chi-square test for Hardy-Weinberg equilibrium; $\mathrm{G}^{2}$ : Likelihood ratio test for Hardy-Weinberg equilibrium; df: degree of freedom; Probability level: 0.05 .

Table 2. Association of pituitary specific transcription factor 1 genotypes with bodyweight.

\begin{tabular}{ccccccc}
\hline \multirow{2}{*}{ Weeks } & \multicolumn{3}{c}{ Fulani ecotype } & \multicolumn{3}{c}{ Yoruba ecotype } \\
\cline { 2 - 7 } & AA $(28)$ & AB $(15)$ & P-values & AA (35) & AB (11) & p-values \\
\hline 0 & $26.63 \pm 3.05$ & $25.90 \pm 2.94$ & 0.50 & $24.73 \pm 2.41$ & $24.54 \pm 2.49$ & 0.67 \\
1 & $35.58 \pm 11.87$ & $35.92 \pm 15.36$ & 0.84 & $35.86 \pm 5.54$ & $35.45 \pm 6.08$ & 0.69 \\
2 & $52.53 \pm 12.50$ & $52.26 \pm 14.80$ & 0.87 & $50.84 \pm 12.6$ & $50.27 \pm 8.54$ & 0.95 \\
3 & $83.83 \pm 23.75$ & $82.23 \pm 17.02$ & 0.87 & $79.31 \pm 17.19$ & $84.05 \pm 21.58$ & 0.50 \\
4 & $118.25 \pm 24.71$ & $103.10 \pm 15.05$ & 0.04 & $109.76 \pm 17.58$ & $116.80 \pm 31.31$ & 0.39 \\
5 & $185.53 \pm 33.06$ & $177.47 \pm 23.12$ & 0.37 & $145.58 \pm 25.70$ & $148.45 \pm 32.83$ & 0.81 \\
6 & $225.00 \pm 30.73$ & $209.66 \pm 20.86$ & 0.08 & $177.25 \pm 31.49$ & $177.81 \pm 42.08$ & 0.85 \\
7 & $259.48 \pm 28.34$ & $255.87 \pm 18.43$ & 0.55 & $217.53 \pm 27.33$ & $223.55 \pm 33.90$ & 0.44 \\
8 & $311.76 \pm 39.50$ & $317.13 \pm 43.95$ & 0.72 & $251.48 \pm 28.08$ & $263.81 \pm 25.44$ & 0.10 \\
9 & $352.21 \pm 45.82$ & $363.26 \pm 36.49$ & 0.48 & $304.80 \pm 30.80$ & $323.41 \pm 40.90$ & 0.06 \\
10 & $414.62 \pm 56.72$ & $435.79 \pm 28.57$ & 0.21 & $347.68 \pm 35.83$ & $362.31 \pm 49.19$ & 0.16 \\
11 & $483.94 \pm 62.97$ & $510.09 \pm 45.21$ & 0.19 & $413.76 \pm 42.93$ & $430.54 \pm 53.54$ & 0.21 \\
12 & $536.63 \pm 59.01$ & $560.23 \pm 45.10$ & 0.21 & $482.41 \pm 41.77$ & $510.46 \pm 48.04$ & 0.03 \\
\hline
\end{tabular}

$\mathrm{AA}$ and $\mathrm{AB}$ observed genotypes; p-values: Probability values. 


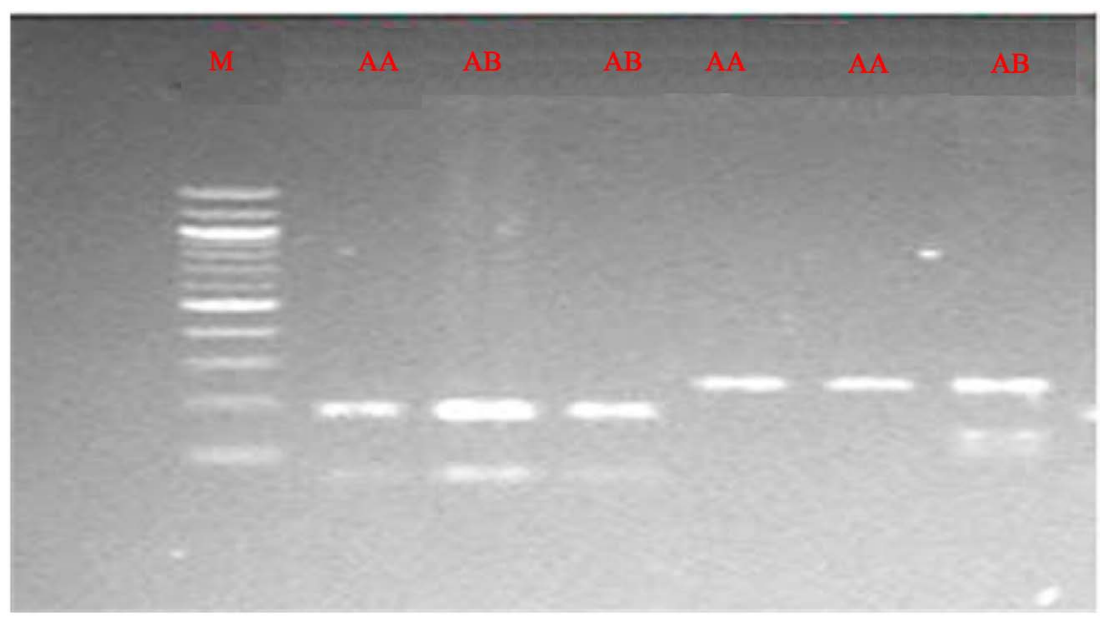

Figure 2. The $243 \mathrm{bp}$ fragment produced by PCR-RFLP of exon 1 of PIT 1 gene in the sampled Nigerian indigenous chicken. M-Molecular marker of 100 bp; AA and AB-observed genotypes.

\section{Discussion}

Pituitary transcript factor 1 is a pituitary specific POU-domain DNA binding factors, which help to aid trans-activates promoters of growth hormone (GR), prolactin (PRL) and thyroid stimulating hormone beta (TSH beta) encoding genes [16].

PIT-1 gene has been reported to comprise 6 exons in mammals and 7 exons in birds [17] [18] [19]. In chicken, this gene is located on chromosome 1 (Chicken Genome Browser Gateway). Reference [14] reported that Twenty-three single-nucleotide polymorphism (SNP) was observed in the 2400-bp discrete region of the PIT-1 gene in chickens.

PIT-1 gene was polymorphic in this study with only two genotypes, AA and $\mathrm{AB}$. The BB homozygous genotype was not identified in the sampled chickens. However, this is in contrary with [20] that reported the presence of homozygous TT at intron 5 of PIT-1 in Chinese Xinghua chicken.

Allele A (0.85) was more prevalent than Allele B (0.15) in the studied population. The frequency of AA genotype (0.71) was higher than AB genotype (0.29). These observed frequencies was in contrary with the result reported by [20] that allele C (0.94) was higher than allele B (0.06) and genotype frequency for CC (0.73) was higher than that of CT (0.20) and TT (0.06) in Chinese Xinghua chicken.

Also in contrary with [12] that reported allele $\mathrm{C}(0.14)$ had a lower value compared with allele D (0.86) and genotypic frequency of CC (0.01), CD (0.25) and DD (0.73) in Chinese indigenous and Western goose.

Hardy-Weinberg probability for chi square $\left(\chi^{2}\right)$ analysis obtained for this study is 1.07 . This probability value implies that the PIT-1 locus in the sampled population indicates that the population is at equilibrium. Reference [12] reported a deviation from Hardy-Weinberg $(\mathrm{p}<0.01)$ in PIT-1 gene in Chinese indigenous and Western goose populations which might be due to the small sample size and six ecotypes of goose used. 
In this study, there was no significant association $(\mathrm{p}>0.05)$ between AA and $\mathrm{AB}$ genotypes and growth as explained by body weight of Nigerian indigenous chicken except week 12. The results obtained is consistent with that [21] who identified that IGF-1 genotypes had no significant association for bodyweight at 140, 265 and 365 days in White Leghorn strain chickens while there was a significant association $(\mathrm{p}<0.05)$ of $\mathrm{AA}$ and $\mathrm{AB}$ genotypes with body weight of Yoruba ecotype at 12 week only. Individuals with $A B$ genotype had higher body value (539 g) compared to the AA genotypes ( $506 \mathrm{~g}$ ) individual at week 12 . This agrees with report by [22] that body weight was higher at 4, 8, 12 and 14 weeks in AA genotype of IGF-1 than in AB and BB genotypes in the Khai Mook Esarn and Soi Pet population of chickens.

\section{Conclusion}

It can be concluded that PIT-1 gene has two polymorphic types in the sampled population of Nigerian Indigenous Chicken and could be associated with body weight at week 4 and week 12 in Fulani and Yoruba Ecotypes chicken respectively. Further research should be carried out with large sample size and lengthen duration in order to validate the obtained association of PIT-1 genotypes with growth of Nigerian indigenous chicken.

\section{Acknowledgements}

We appreciate Dr. Fagbohun and his research team for the assistance rendered during laboratory analysis.

\section{Authors' Contribution}

M. O. and S. F. drafted the proposal, R. B. and S. F. participated in the field work and laboratory analysis, R. B., S. F. and M. K. participated in the data analysis and interpretation, A. R., F. O., F. A. and B. S. contributed to the correction of the final draft of the manuscript. All authors read, corrected and approved the final manuscript.

\section{Conflicts of Interest}

The authors declare no conflicts of interest regarding the publication of this paper.

\section{References}

[1] Apuno, A.A., Mbap, S.T. and Ibrahim, T. (2011) Characterization of Local Chickens (Gallus gallusdomesticus) in Shelleng and Song Local Government Areas of Adamawa State, Nigeria. Agriculture and Biology Journal of North America, 2, 6-14. https://doi.org/10.5251/abjna.2011.2.1.6.14

[2] Momoh, O.M., Ehiobu, N.G. and Nwosu, C.C. (2007) Egg Production of Two Nigerian Local Chicken Ecotypes under Improved Management. Proceedings 32nd Annual Conference of Nigerian Society for Animal Production, Calabar, 18-22 March 2007, 278-281. 
[3] Adedeji, T.A., Ojedapo, L.O., Ige, A.O., Ameen, S.A., Akinwumi, A.O. and Amao, S.R. (2008) Genetic Evaluation of Growth Performance of Pure and Crossbred Chicken Progenies in a Derived Savannah Environment. Proceedings of the 13 th Annual Conference of Animal Science Association of Nigeria, Zaria, 15-19 September 2008, 8-12.

[4] Tadelle, D., Million, T., Alemu, Y. and Peters, K.J. (2003) Village Chicken Production Systems in Ethiopia: Flock Characteristics and Performance. Livestock Research in Rural Development, 15, Article No. 9.

http://www.lrrd.org/lrrd15/1/tadea151.htm

[5] Olawunmi, O.O., Salako, A.E. and Afuwape, A.A. (2008) Morphometric Differentiation and Assessment of Function of the Fulani and Yoruba Ecotype Indigenous Chickens of Nigeria. International Journal of Morphology, 26, 975-980. https://doi.org/10.4067/S0717-95022008000400032

[6] Ajayi, F.O. and Agaviezor, B.O. (2009) Phenotypic Characteristics of Indigenous Chicken in Selected Local Government Areas in Bayelsa State, Nigeria. Proceedings of the 3rd Nigeria International Poultry Summit, Abeokuta, 22-26 February 2009, 75-78.

[7] Miyai, S., Yoshimera, S., Iwasaki, Y., Takeokoshi, S., Llyod, R.V. and Osamua, R.Y. (2015) Induction of GH, PRL and TSH beta mRNA by Transfection of PIT-1 in a Human Pituitary Adenine Derived Cell Line. Cell Tissue Research, 322, 269-277. https://doi.org/10.1007/s00441-005-0033-z

[8] Taha, D., Mullis, P.E., Ibanez, L. and de Zegher, F. (2005) Absent or Delayed Adrenarche in Pit-1/POU1F1 Deficiency. Hormone and Metabolic Research, 64, 175-179. https://doi.org/10.1159/000088793

[9] Lee, P.Y., Costumbrado, J., Hsu, C.Y. and Kim, Y.H. (2012) Agarose Gel Electrophoresis for the Separation of DNA Fragments. Journal of Visualized Experiments, 62, 3293. https://doi.org/10.3791/3923

[10] Tanaka, M., Yamamoto, I., Ohkubo, T., Wakita, M., Hoshino, S. and Nakashima, K. (1999) cDNA Cloning and Developmental Alterations in Gene Expression of the Two Pit-1/GHF-1 Transcription Factors in the Chicken Pituitary. General and Comparative Endocrinology, 114, 441-448. https://doi.org/10.1006/gcen.1999.7270

[11] Sewalem, A., Morrice, D.M., Law, A., Windsor, D., Haley, C.S., Ikeobi, C.O.N., Burt, D.W. and Hocking, P.M. (2002) Mapping of Quantitative Trait Loci for Body Weight at Three, Six, and Nine Weeks of Age in a Broiler Layer Cross. Poultry Science, 81, 1775-1781. https://doi.org/10.1093/ps/81.12.1775

[12] Cheng, J., et al. (2011) Genetic Variation of Pit-1 Gene in Chinese Indigenous and Western Goose Populations. African Journal of Biotechnology, 8, 3147-3153.

[13] Musa, A.A., Orunmuyi, M., Akpa, G.N., Olotunmogun, A.K. and Balogun, N.B. (2016) Effects of Insulin-Like Growth Factor I (IGF-I) Polymorphism on Bodyweight of Nigerian Indigenous Chickens. African Journal of Agricultural Research, 11, 1194-1198. https://doi.org/10.5897/AJAR2015.10485

[14] Nie, Q., Lei, M., Quyang, J., Zeng, H., Yang, G. and Zhang, X. (2005) Identification and Characterization of Single Nucleotide Polymorphisms in 12 Chicken Growth-Correlated Genes by Denaturing High Performance Liquid Chromatography. Genetic Selection Evolution, 37, 339-360. https://doi.org/10.1186/1297-9686-37-4-339

[15] SAS (2002) Stastical Analysis System, Computer Software, Version 9.

[16] Van As, P., Buys, N., Onagbesan, O.M. and Decuypere, E. (2006) Complementary DNA Cloning and Ontogenic Expression of Pituitary-Specific Transcription Factor of Chickens (Gallus domesticus) from the Pituitary Gland. Genetic and Compara- 
tive Endocrinology, 120, 127-136. https://doi.org/10.1006/gcen.2000.7529

[17] Tatsumi, K., Notomi, T., Amino, N. and Miyai, K. (1992) Nucleotide Sequence of the Complementary DNA for Human Pit-1/GHF-1. Biochimica et Biophysica Acta, 129, 231-234. https://doi.org/10.1016/0167-4781(92)90494-K

[18] Wong, E.A., Silsby, J.L. and Halawani, M.E. (1992) Complementary DNA Cloning and Expression of Pit-1/GHF-1 from the Domestic Turkey. DNA Cell Biology, 11, 651-660. https://doi.org/10.1089/dna.1992.11.651

[19] Yamada, S., Hata, J. and Yamashita, S. (1993) Molecular Cloning of Fish Pit-1 cDNA and Its Functional Binding to Promoter of Gene Expressed in the Pituitary. Journal Biology Chemistry, 268, 24361-24366.

[20] Nie, Q., Fang, M., Xie, L., Zhou, M., Liang, Z., Luo, Z., Wang, G., Bi, W., Liang, C., Zhang, W. and Zhang, X. (2008) The PIT1 Gene Polymorphisms Were Associated with Chicken Growth Traits. BMC Genetics, 9, 20-25.

https://doi.org/10.1186/1471-2156-9-20

[21] Nagaraga, S.C., Aggrey, S.E., Yao, J., Zadworny, D., Farfulad, R.W. and Kumnlein, N. (2000) Trait Associated Genetic Marker near the IGF-1 Gene in Egg Laying Chickens. Journal of Heredity, 91, 150-156. https://doi.org/10.1093/jhered/91.2.150

[22] Promwatee, N., Laopaiboon, B., Vongpralub, T., Phasuk, Y., Kunhareang, S., Boonkum, W. and Duangjinda, M. (2013) Insulin-Like Growth Factor I Gene Polymorphism Associated with Growth and Carcass Traits in Thai Synthetic Chickens. Genetic Molecular Research, 12, 4332-4341.

https://doi.org/10.5897/AJAR2015.10485 